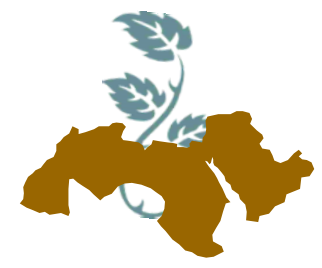

\title{
MOLECULAR CHARACTERIZATION OF TUMOR NECROSIS FACTOR- A (TNFA) GENE IN EGYPTIAN RIVER BUFFALOES
}

\author{
Aboelenin, M.M ${ }^{1}$; K.F. Mahrous ${ }^{1}$, M.A. Rashed ${ }^{2}$ and M.A. Sallam ${ }^{2}$ \\ 1- Cell Biology Dept., National Research Centre, Giza, Egypt \\ 2- Genetics Dept., Faculty of Agriculture, Ain Shams University, Cairo, Egypt
}

Keywords: Egyptian river buffaloes, Tumor Necrosis Factor- $\alpha$, PCR-RFLP, Single nucleotide polymorphism

\section{ABSTRACT}

Tumor Necrosis Factor- $\alpha$ (TNF $\alpha$ ) is a cytokine signaling protein which has an important role in the immune system regulation and affect female reproductive performance. The objective of this study was investigation the TNFa gene polymorphism and its potential effects in female buffaloes fertility. The DNA was extracted from the blood of 81 buffalo females and a $592 \mathrm{bp}$ fragment contains the full coding region of TNFa-exon 4 was amplified by PCR which subsequently treated with Rsal restriction enzyme. The PCR-RFLP pattern showed that all the animals had fixed $\mathrm{CC}$ genotype and $\mathrm{T}$ allele was not detected. Sequencing of amplified fragment (GenBank accession No. KY885010) flowed by sequence alignment with GenBank database revealed that the river buffalo target sequence was homologues to cattle than goat, sheep, human and mouse on DNA and amino acids levels. Comparison of TNFa amplicon with homologues Bubalus bubalis records in the GenBank detected 3 SNPs in exon 4. Two of these SNPs were synonymous while the third located in the 3 UTR. Different effects of some of discovered SNPs on RNA cis-regulatory elements and hn mRNA and mature mRNA secondary structures were predicted.

\section{INTRODUCTION}

Tumor Necrosis Factor- $\alpha$ (TNF $\alpha$ ) is a cytokine signaling protein which is a mediator of inflammation and has several functions in the immune sys- tem that include regulation of the immune response against infections, lymphoid tissue development at the lymph nodes and apoptosis induction (Cordero-Coma and Sobrin, 2015). Moreover, many evidence suggested a possible role for TNFa in female ovulation cycle. Injection of TNFa alone induces ovulation in some rat ovary while luteinizing hormone ( $\mathrm{LH}$ ) injection in combination with TNFa increased both of ovulation rate and progesterone secretion compared to $\mathrm{LH}$ alone (Brannstrom et al 1995). Furthermore, local injection of TNFa antiserum in the ovarian follicle blocked ovulation in the ewes ovary (Murdoch et al 1997). TNFa gene in river buffalo was assigned to chromosome BBU 2p21-22 (lannuzzi et al 2015). According to GenBank record with accession number JQ043173.1 the river buffalo TNF- $\alpha$ gene is about $2 \mathrm{~kb}$ long and has 4 exons and 3 introns.

Higuchi et al (1999) discovered a C to T SNP within TNFa-exon 4 was recognized by polymerase chain reaction-restriction fragment length polymorphism (PCR-RFLP) method using restriction enzyme Rsal (RFLP-Rsal). The SNP was synonymous and locates in the third nucleotide within a codon codes for Tyrosine $(\mathrm{Y})$. In a study on this SNP in 170 Holstein cattle using the same technique Shirasuna et al (2011) found that CC genotype had earlier ovulation within 3 weeks postpartum and shorter days open than TT genotype. Genotyping of the same SNP in 315 Holstein cows but using the restriction enzyme Afal (RFLP-Afal) revealed that the first ovulation after parturition was earlier in the animals with CC (uncut PCR product) and CT genotypes than the animals with TT genotypes (Kawasaki et al 2014).

Although the buffalo (Bubalus bubalis) can adapt to harsh environments and poor quality for- 
age, the buffalo has been traditionally regarded as a poor breeder due to its poor fertility in the majority of conditions under which they are raised. The reproductive problems could be manifested mainly as late maturity, long postpartum anoestrous intervals, poor expression of oestrus, poor conception rates and long calving intervals (Perera, 2011). So, in the present study, RFLP assay and DNA sequence analysis were performed to examine genotypes and screen SNPs in exon 4 of TNFa gene in female Egyptian buffaloes.

\section{MATERIALS AND METHODS}

This investigation was carried out in Cell Biology Department, National Research Centre, Giza, Egypt.

\section{Blood collection and DNA extraction}

A total of 81 blood samples were collected from healthy and unrelated Egyptian river buffalo females. 30 samples were collected from the farm of Cattle Information System/Egypt (CISE) and 51 samples were collected from Agricultural Experiments Station (AES), Faculty of Agriculture, Cairo University, Giza, Egypt. $10 \mathrm{ml}$ of blood samples were collected in sterile $15 \mathrm{ml}$ tubes containing $0.5 \mathrm{ml}$ of $0.5 \mathrm{M}$ EDTA solution (PH 8.0). Genomic DNA was extracted from the whole blood according to the method described by Miller et al (1988) with minor modifications. The DNA concentration was determined, using Nano Drop1000 thermo scientific spectrophotometer and then diluted to the working concentration of $50 \mathrm{ng} / \mu \mathrm{l}$.

\section{Animals genotyping and TNFa-exon 4 sequenc- ing}

A DNA fragment which includes all the coding region of TNFa-exon 4 and part of its 3 ' untranslated region (3`UTR) were amplified using the primer pair TNF4-F (5 CAGGATGTGGAGAGTAG AACTGA3') and TNF4-R (5'TGAGCCCCTAATT CCCTTTCTA3') which were designed using Primer3 online software (Yazdani et al 2010, http://primer3.ut.ee/) based on the sequence of GenBank record JQ043173.1. Polymerase Chain Reaction (PCR) were performed in a $25 \mu$ reaction volume, which included $50 \mathrm{ng}$ genomic DNA, $50 \mathrm{ng}$ each primer, $200 \mu \mathrm{M}$ each dNTP, $2.5 \mu \mathrm{l}$ 10X PCR buffer and $0.5 \mu$ Taq DNA polymerase (Promega, Madison, WI, USA). Amplification was carried out in a thermocycler programmed as follows: An initial start separation cycle at $94^{\circ} \mathrm{C}$ for 2 min, 35 cycles including a denaturation step at $94^{\circ} \mathrm{C}$ for $30 \mathrm{sec}$, an annealing step at $60^{\circ} \mathrm{C}$ for $30 \mathrm{sec}$ and polymerization step at $72^{\circ} \mathrm{C}$ for $45 \mathrm{sec}$, A final extension cycle at $72^{\circ} \mathrm{C}$ for 10 minute. The PCR products were screened by electrophoresis on $2 \%$ agarose gel in 0.5X TBE buffer stained with ethidium bromide and were visualized with UV transilluminator.

PCR product was digested by $R$ sal restriction enzyme (Thermo Scientific, Dreieich, Germany) at $37^{\circ} \mathrm{C}$ for $30 \mathrm{~min}$ according to the procedure provided by the manufacturer. Digested products were separated by electrophoresis in $2 \%$ agarose gel in $0.5 \mathrm{X}$ TBE buffer stained with ethidium bromide and were visualized with UV transilluminator.

\section{Purification and sequencing of PCR products}

The PCR products of selected samples were purified using GeneJET Gel Elution Kit (Thermo Scientific, Dreieich, Germany). The purified PCR products were sequenced using an automated sequencing service (Macrogen, Korea).

\section{Data analysis}

Alignment of the sequences were performed with GenBank database BLAST tool (http://www.ncbi.nIm.nih.gov/BLAST/) to identify the homology between target TNFa region and the other TNFa sequences on the GeneBank database. The effect of discovered SNPs on splicing site strength, RNA cis-regulatory elements and pre and mature mRNA secondary structures were predicted using SplicePort (Dogan et al 2007), RegRNA 2.0 (Chang et al 2013) and RNAsnp (Sabarinathan et al 2013) online softwares respectively

\section{RESULTS AND DISCUSSION}

The time needed to resume the ovarian activity after parturition has an important role in fertility postpartum in dairy animals. A cytosine to thymine SNP within TNFa-exon 4 was found to have a statistical correlation with first ovulation postpartum in cattle females (Shirasuna et al 2011 and Kawasaki et al 2014). Depending on high degree of similarity between the buffaloes and cattle genomes (Tantia et al 2011) the association between this SNP and reproductive performance of buffalo females was examined in this study.

PCR-RFLP genotyping 

river buffaloes

The DNA was extracted from 81 buffalo females. The target fragment contains the full coding region of TNFa-exon 4 was successfully amplified by PCR using the designed primers and a PCR product with 592 bp was validated (Fig. 1-A). Subsequently, the PCR product was treated with Rsal and the pattern of PCR-RFLP was analyzed also by electrophoresis in $2 \%$ agarose gel (Fig. 1-B).

In this study no polymorphism in the target position within TNFa-exon 4 was discovered among all buffalo females. All the animals had a single PCR-RFLP pattern consists of 2 bands had the molecular weights 232 and $360 \mathrm{bp}$ approximately (Fig. 1-B), this pattern represents CC genotype.
This result was confirmed by DNA sequencing of TNFa PCR product of different samples which shows a cytosine nucleotide located in the SNP of interest site and the restriction site of Rsal enzyme (Fig. 1-C).

In contrast to this result which confirms absence of $\mathrm{T}$ allele in the tested buffalo females, $\mathrm{T}$ allele frequency was $31.36 \%$ (Shirasuna et al 2011) and $57.08 \%$ (Kawasaki et al 2014) in Holstein cows. As the result to the identified monomorphism in the target SNP site it was not possible find a statistical relationship between this SNP and fertility of buffaloes females.

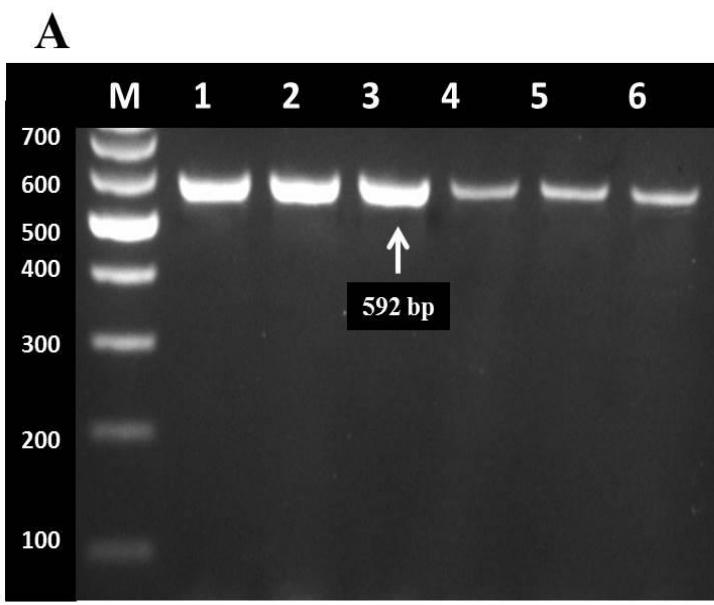

\section{B}

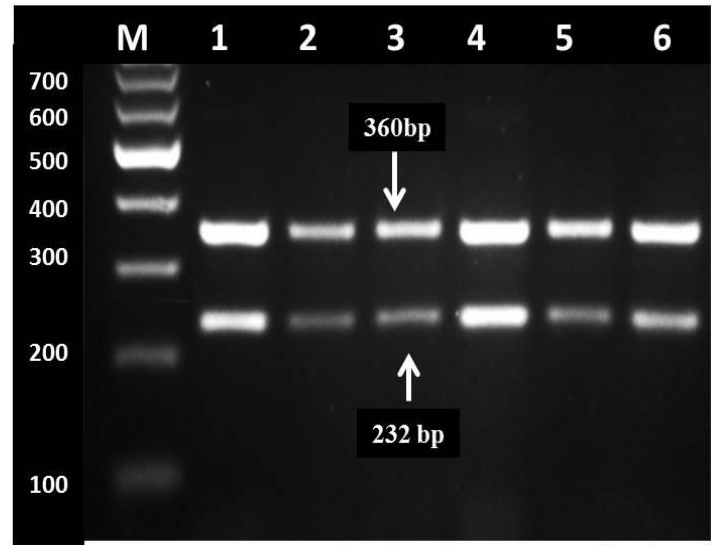

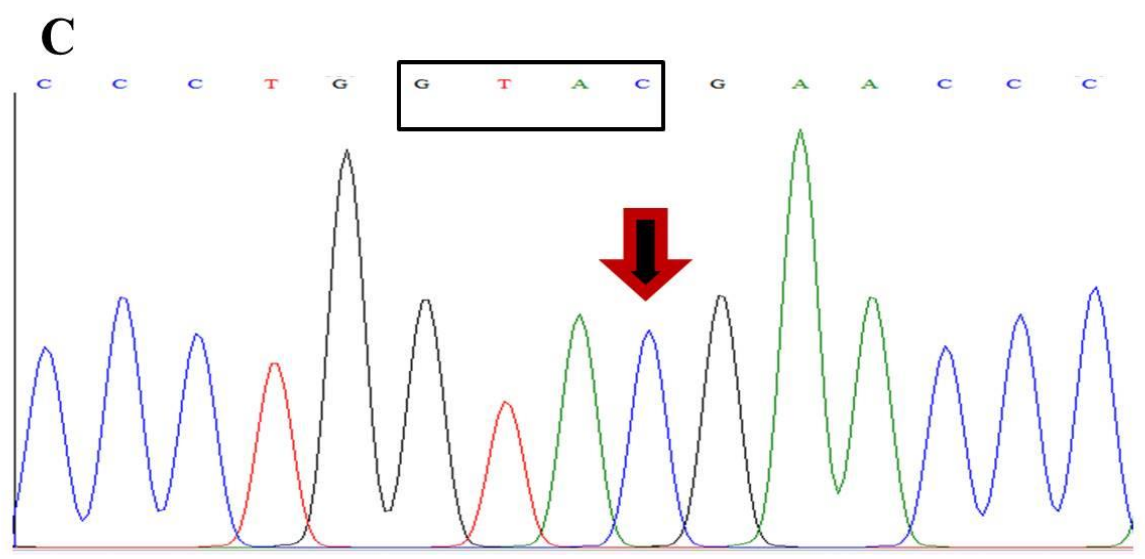

Fig. 1. PCR Product, PCR-RFLP pattern and sequencing result of amplified TNFa-exon 4 fragment. (Fig. 1 -A) $2 \%$ agarose gel electrophoresis of amplified PCR product of TNFa-exon 4 fragment. $M=100$ bp molecular marker. Lanes 1,4 and 5=Animals from CISE. Lanes 2, 3 and $6=$ Animals from AES. (Fig. 1-B) PCR-RFLP pattern of TNFa-exon 4 amplicon after digestion by Rsal. $\mathrm{M}=100 \mathrm{bp}$ molecular marker. Lanes 1-3=Animals from CISE. Lanes 4-6= Animals from AES (Fig. 1-C) A part of DNA sequencing chromatogram of TNFa-exon 4 amplified fragment. The black box indicates the restriction site of $R s a l$ and the wide arrow pointing to the target $\mathrm{C}$ to T SNP position. 


\section{Sequencing and analysis of amplified se- quence}

Sequencing of amplified fragment (GenBank accession No. KY885010) followed by searching for sequence similarity using BLAST software against GenBank database revealed that the amplified 592 bp sequence consists of a part of intron 3 (nucleotides from 1 to 69 ), full coding region of TNFa-exon 4 (nucleotides from 70 to 488), stop codon (nucleotides from 489 to 491 ) and 3 ' untranslated region ( 3 ' UTR - nucleotides from 492 to 592). The first 2 nucleotides in the 5 of coding region represent the second and third letters in a codon starts with the last nucleotide in the $3{ }^{\prime}$ end of exon 3 , while the remaining nucleotides in the coding region of TNFa-exon 4 code for 139 amino acids represent about $59.4 \%$ of the total amino acids of buffalo TNFa protein (GenBank accession numbers JQ043173.1 and ABO15707.1).

Nucleotides sequence homology analysis of target sequence in orthologous TNFa genes showed there is a similarity between the buffalo sequenced fragment and cattle (98\%), sheep $(96 \%)$, goat $(95 \%)$ and human $(81 \%)$ while mouse TNFa-exon 4 do not show significant homology (Fig. 2-A). The phylogenetic tree of the nucleotides sequences (Fig. 2-B) approved that the TNFa-exon 4 sequence is more homologues between buffalo and cattle while the sequence of sheep is more homologues to goat.

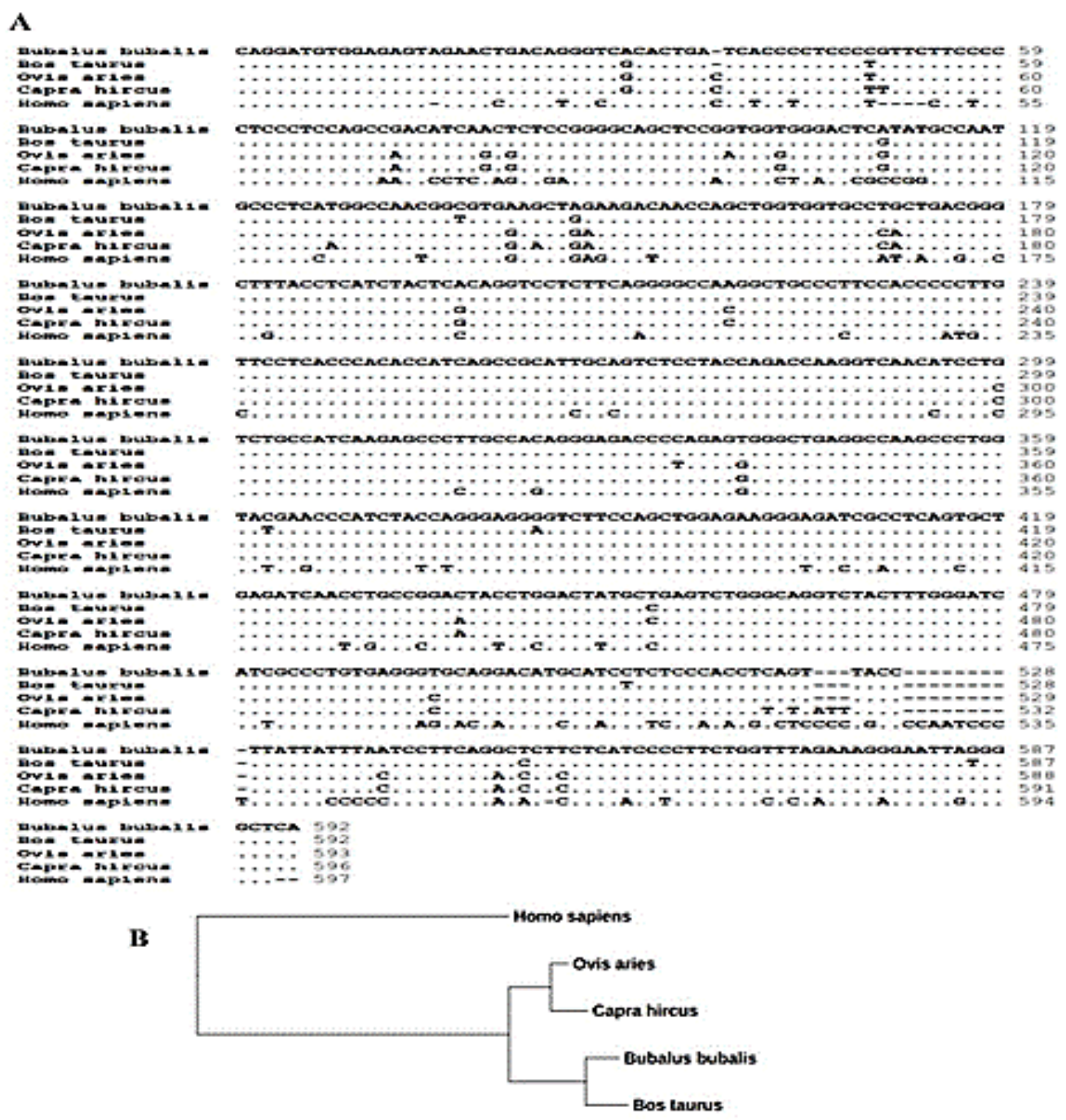

Fig. 2: Multiple sequence alignment and phylogenetic tree of nucleotide sequences of TNFa in some species. Multiple sequence alignment $(A)$ and phylogenetic tree $(B)$ of nucleotide sequences of TNFaexon 4 in Egyptian buffaloes (Bubalus bubalis), cattle (Bos taurus), sheep (Ovis aries), goat (Capra hircus) and human (Homo sapiens). 

river buffaloes

On the other hand, the nucleotide sequences of buffalo, cattle, sheep and goat are more similar than the human sequence. These results is in accordance with the fact that both of buffalo cattle belong to subfamily Bovinae while sheep and goat belong to subfamily Caprinae and the 4 species belong to family Bovidae but human belongs to more distance taxa within the taxonomic tree of kingdom Animalia (https://www.itis.gov/).

On the level of amino acids sequence the homology between buffalo amino acids sequence and those of cattle, sheep, goat, human and mouse was $100 \%, 92 \%, 91 \%, 82 \%$ and $73 \%$ respectively (Fig. 3-A). The amino acids sequence of TNFa fragment is completely similar between buffalo and cattle while the sequence of sheep is more similar to goat, and the amino acids sequences of buffalo, cattle, sheep and goat are more homologues than the human and mouse sequences (Fig. 3-B) which are is in line with in the taxonomic relationship among these species that mentioned above.

A

\begin{tabular}{|c|c|}
\hline Bubalus bubalis & DINSPGQLRKNDSYANALYANGVKLEDNQLVVPADGLYLIYSQVLFRGQGCPSTPLFLTHTISRIAVSYQ 70 \\
\hline Bos taurus & \\
\hline Ovis aries & N.SA......... \\
\hline Capra hircus & N.SA.....G......K...A.K... \\
\hline Homo sapiens & NPQAE. . Q.LNRR . ..L....E.R.... \\
\hline Mus musculus & 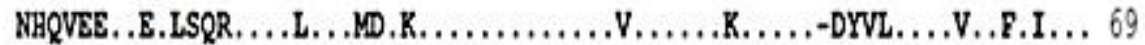 \\
\hline
\end{tabular}

Bubalus bubalis TKWNILSAIKSPCHRETPEWAEAKPWYEPIYQGGVRQLEKGDRLSAEINLPDYLDYAESGQVYFGIIAL 139

Bos taurus

Ovis aries

Capra hircus

Homo sapiens

Mus musculus
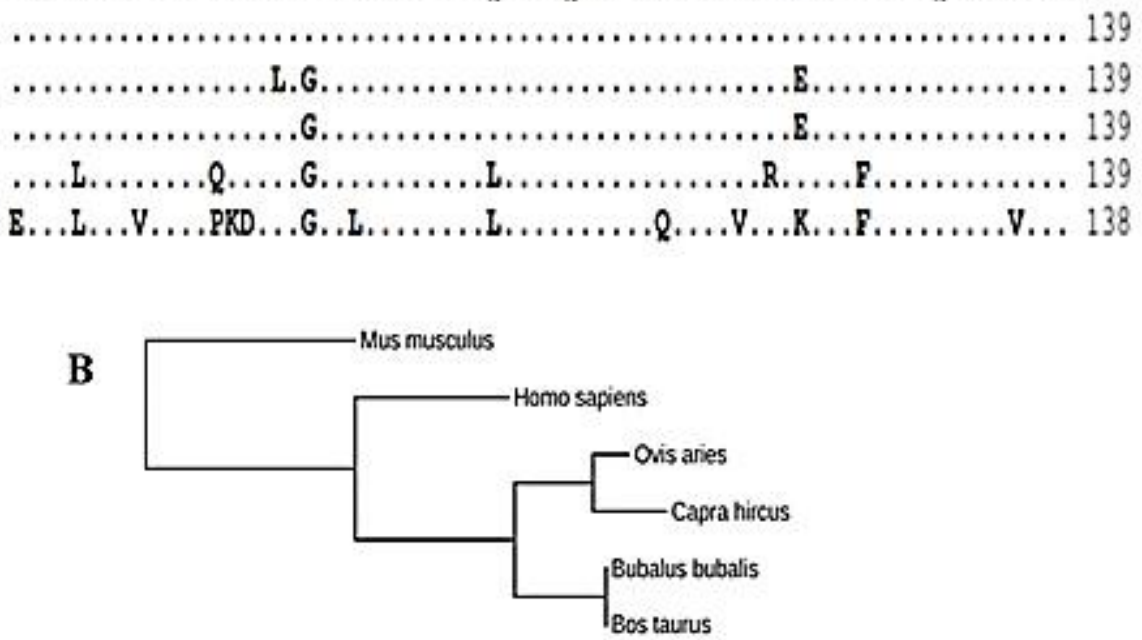

Fig. 3. Multiple sequence alignment and phylogenetic tree of amino acids of TNFa in some species Multiple sequence alignment $(A)$ and phylogenetic tree $(B)$ of amino acids sequence of TNFa-exon 4 in Egyptian buffaloes, cattle, sheep, goat, human and mouse (Mus musculus)

Moreover, the sequence identity equal $100 \%$ between amino acids sequence of TNFa-exon 4 compared to $98 \%$ nucleotides sequences identity which mean that all the 6 SNPs between buffalo and cattle DNA sequences that located in the coding region of TNFa-exon 4 (Fig. 2-A) are synonymous and do not alter the amino acid sequence which is conserved between the 2 species.
Comparison of the sequence of amplified TNFa fragment with homologues Bubalus bubalis sequences in the GenBank database indicate 3 SNPs among these sequences which listed in Table (1). Interestingly, all the detected SNPs among Bubalus bubalis sequences are similar to 3 out of 11 SNPs were found between river buffalo and cattle sequences (Fig. 2-A). 2 SNPs (A 110G and 
Table 1.The detected SNPs between amplified TNFa sequence and its homologues Bubalus bubalis sequences in GenBankdatabase.

\begin{tabular}{|c|c|c|c|c|c|}
\hline SNP & Position & $\begin{array}{l}\text { Mutated } \\
\text { codon }\end{array}$ & $\begin{array}{l}\text { Type of ami- } \\
\text { no acid mu- } \\
\text { tation (posi- } \\
\text { tion) }\end{array}$ & Alleles & GenBankaccetion number \\
\hline A110G & exon 4 & $\begin{array}{l}\text { TCA to } \\
\text { TCE }\end{array}$ & $\begin{array}{c}\text { Synonymous } \\
\text { S to } S\end{array}$ & $\begin{array}{c}A \\
A \& G\end{array}$ & $\begin{array}{l}\text { EB-TNFa, NW_005782253.1, } \\
\text { XM_006041931.1, XM_006041930.1, } \\
\text { AB246789.1, EF562450.1, EF562449.1, } \\
\text { EF424255.1, AY221123.1 \& KX029323.1 } \\
\text { JQ043173.1 }\end{array}$ \\
\hline G383A & exon 4 & $\begin{array}{c}\mathrm{GGG} \text { to } \\
\mathrm{G} \overline{\mathrm{G}} \underline{\mathrm{A}}\end{array}$ & $\begin{array}{c}\text { Synonymous } \\
G \text { to } G\end{array}$ & A & $\begin{array}{l}\text { EB-TNFa, NW_005782253.1, } \\
\text { JQ043173.1, XM_006041931.1, } \\
\text { XM_006041930.1, AB246789.1, } \\
\text { EF562450.1, EF562449.1, EF424255.1 \& } \\
\text { AY221123.1 } \\
\text { KX029323.1 }\end{array}$ \\
\hline C510T & 3`UTR & - & - & $\begin{array}{l}\mathrm{C} \\
\mathrm{T}\end{array}$ & $\begin{array}{l}\text { EB-TNFa, NW_005782253.1, } \\
\text { JQ043173.1, XM_006041931.1 \& } \\
\text { XM_006041930.1 } \\
\text { AB246789.1 }\end{array}$ \\
\hline
\end{tabular}

G383A) were located in the coding sequence while the third SNP (C510T) was found in 3' UTR.

Both of A110G and G383A are synonymous SNPs and did not change the amino acids sequences of river buffalo TNFa protein. Based on the homology between river buffalo and cattle genomes (Tantia et al 2011) we used the cattle codon usage table (http://flowgene.az/) as reference to compare the codon usage in river buffalo. G383A SNP altered the GGG codon to GGA codon which code to amino acid glycine and have similar frequency (25 and $23 \%$ respectively). On the other hand, A110G SNP changed TCA codon to TCG codon and both of them code for the amino acid serine but the first codon frequency is $14 \%$ compare to second codon which has lowest frequency (7\%) among the 6 codons that code for serine. The synonymous codons with different codon usage may lead significant change in protein translation level in the eukaryotic cells (Powell and Dion, 2015).
The strength of intron 3-3`splicing site was calculated using Splice Port online software (Dogan et al 2007) and the score estimated to be 1.48. Both of G383A and C510T SNPs did not affect the strength of $3^{`}$ splicing site while A110G SNP increased the $3^{\prime}$ splicing site score to be 1.79. The DNA sequence was scanned using RegRNA 2.0 online software (Chang et al 2013) to investigate the effect of discovered SNPs in the RNA cis-regulatory elements within the TNFa premRNA. TheA110G and G383A SNPs created 2 exonic splicing enhancers are recognized by the splicing regulatory proteins SC35 and ASF/SF2 (Table 2). SplicePort software calculates the score of the splicing site based on $\pm 80 \mathrm{bp}$ around the splicing site which explains $3{ }^{\prime}$ splicing site score rising due the exonic splicing enhancer which formed by A110G SNP (about 40 bp upstream3 splicing site) compared to exonic splicing enhancer which formed by G383A SNP that did not affect the 3 'splicing site score because it positioned outside this region.

Table 2.The effect of detected buffalo TNFa gene SNPs on RNA cis-regulatory elements within TNFa premRNA.

\begin{tabular}{|cccc|}
\hline SNP & Effect & Motif & Binding factor \\
\hline A110G & Creat: Exonic splicing enhancer-Homo sapiens & 105 gactcĞta 112 & SC35 \\
G383A & Creat: Exonic splicing enhancer - Homo sapiens & 377 gggaggA 383 & ASF/SF2 \\
\hline
\end{tabular}



river buffaloes

The secondary structure of both of mrna of premRNA and mature mRNA affect several biological processes such as transcription, translation, mRNA splicing and mRNA stability (Wan et al 2014). Depending on this the local secondary structure of river buffalo TNFa gene transcript was predicted using RNAsnp online server (Sabarinathan et al 2013).

The program parameters were adjusted to compute the mRNA secondary structure $\pm 100 \mathrm{nts}$ around the SNP, so the effect of A110G SNP on the secoondary structure of pre and mature mRNA was caculated separtly because this SNP is pointed 40nts upstream exon-4 starting site which mean that the remaining nucleotides (60 nucleotides out of 100) downstream this SNP which used to compute the secondary structure are different between the pre and mature mRNA. The regions $\pm 100 \mathrm{nts}$ around G383A and C510T SNPs were identical in pre and mature $\mathrm{mRN}$.

The secondary structures of both alleles of A110G (on the pre-mRNA level) and C510T (in pre and mature mRNA levels) SNPs were identicals although there were some differences in the calculated minimum free energy (MFE) (Fig. 4-A \& D). on the contrary, minor difference within the secondary structre and MFE in the level of one base was detected between the alleles of A110G (on the mature mRNA level) and G383A (in pre and mature mRNA levels) SNPs (Fig. 4-B \& C) but those differences were not significant $(P>0.2)$.

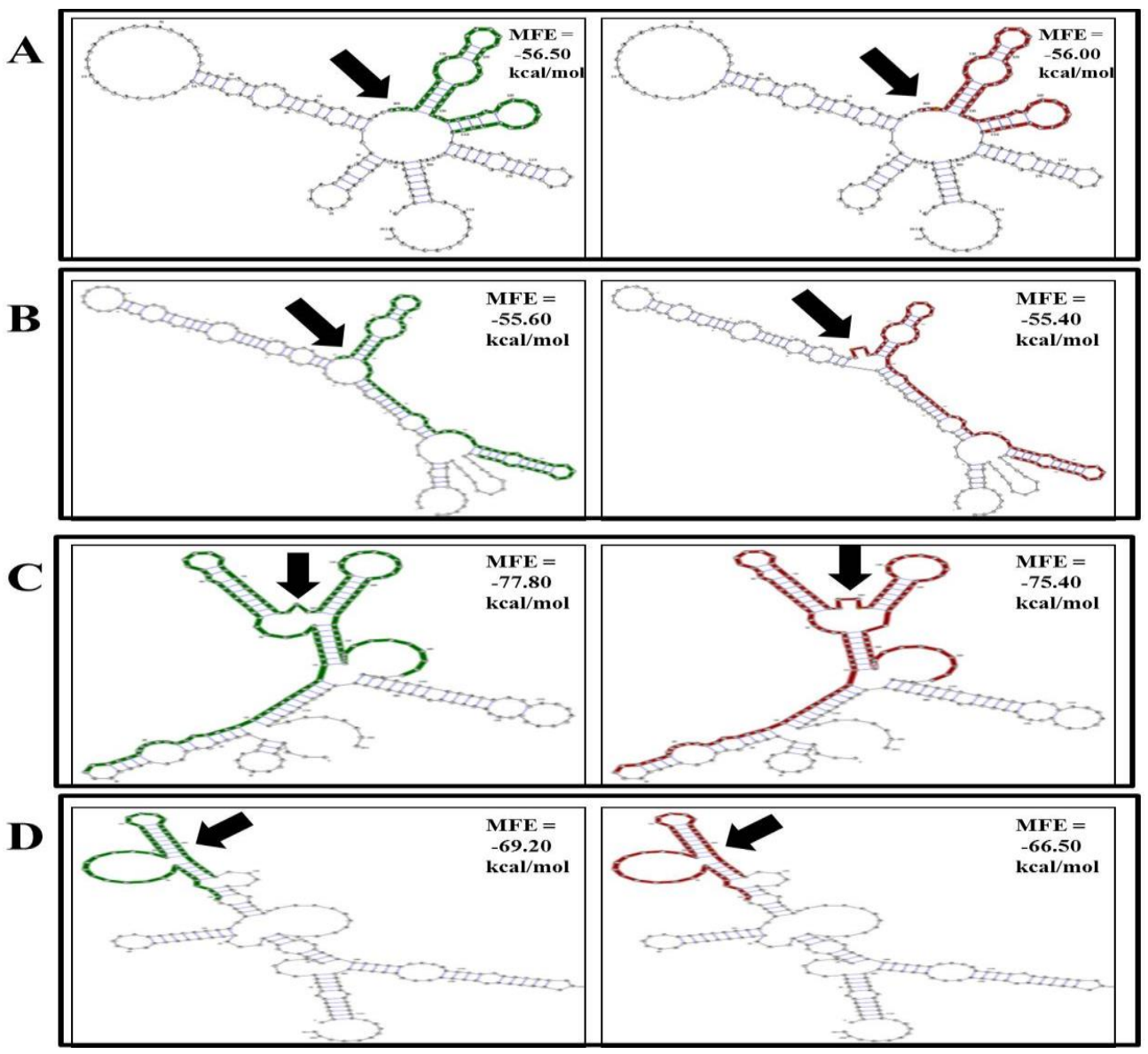

Fig. 4. Predicted changes in pre and mature mRNA local secondary structure of river buffalo TNFa gene transcripts due to detected SNPs. A and B: effect of A110G SNP on secondary structure of premRNA and mature mRNA respectively. C and D: effect of G383A and C510T SNPs respectively on mRNA secondary structures which is the same in pre- and mature mRNA. Left panels represent secondary structure of wildtype sequence while right panels represent secondary structure of mutant sequence. $\mathrm{MFE}=$ minimum free energy of each structure. The arrows erefer to SNP position. 


\section{CONCLUSION}

A 592 bp fragment was amplified by PCR and PCR-RFLP using Rsal revealed that all the animals had CC genotype. A similarity between the amplified nucleotides sequence in buffalo and cattle $(98 \%)$, sheep $(96 \%)$, goat $(95 \%)$ human $(81 \%)$ was observed while mouse TNFa-exon 4 do not show significant homology. The homology between the amino acids sequence of buffalo TNFa fragment and those of cattle, sheep, goat, human and mouse was $100 \%, 92 \%, 91 \%, 82 \%$ and $73 \%$ respectively. Three SNPs were discovered between amplified TNFa fragment and homologues Bubalus bubalis sequences in the GenBank. 2 synonymous SNPs (A110G and G383A) were located in the coding sequence while the third SNP (C510T) was found in $3^{\prime}$ UTR. The A110G and G383A SNPs created 2 exonic splicing enhancers. The secondary structures of both alleles of $A 110 G$ (on the premRNA level) and C510T (in pre and mature mRNA levels) SNPs were identicals, while minor difference within the secondary structre and MFE in the level of one base was detected between the alleles of $A 110 G$ (on the mature mRNA level) and G383A (in pre and mature mRNA levels) SNPs but those differences were not significant $(P>0.2)$.

\section{REFERENCES}

Brannstrom, M., Bonello, N., Wang, L.J. and Norman, R.J. 1995. Effects of tumour necrosis factor alpha (TNF alpha) on ovulation in the rat ovary. Reprod. Fertil. Dev., 7(1), 67-73.

Chang, T.H., Huang, H.Y., Hsu, J.B., Weng, S.L., Horng, J.T. and Huang, H.D. 2013. An enhanced computational platform for investigating the roles of regulatory RNA and for identifying functional RNA motifs. BMC Bioinformatics, 14 (Suppl 2), S4.

Cordero-Coma, M. and Sobrin, L. 2015. Antitumor necrosis factor- $\alpha$ therapy in uveitis. Surv. Ophthalmol., 60 (6), 575-589.

Dogan, R.I., Getoor, L., Wilbur, W.J. and Mount, S.M. 2007. SplicePort--an interactive splice-site analysis tool. Nucleic Acids Res., 35 (Web Server issue), W285-W291.

Higuchi, M., Miyashita, N. and Awata, T. 1999. Rapid communication: a PCR-RFLP in the coding region of the bovine tumor necrosis factor-alpha locus. J. Anim. Sci., 77(12), 34003401.

http://flowgene.az/

http://primer3.ut.ee/

http://www.ncbi.nlm.nih.gov/BLAST/

https://www.itis.gov/ lannuzzi, A., Perucatti, A., Pauciullo, A., Genualdo, V., De Lorenzi, L., Parma, P. and lannuzzi, L. 2015. Fluorescent in situ hybridization mapping of three fecundity genes on cattle, river buffalo, sheep and goat. Caryologia, 68(1), 9-12.

Kawasaki, Y., Aoki, Y., Magata, F., Miyamoto, A., Kawashima, C., Hojo, T., Okuda, K., Shirasuna, K. and Shimizu, T. 2014. The effect of single nucleotide polymorphisms in the tumor necrosis factor-alpha gene on reproductive performance and immune function in dairy cattle. J. Reprod. Dev., 60(3), 173178.

Miller, S.A., Dykes, D.D. and Polesky, H.F. 1988. A simple salting out procedure for extracting DNA from human nucleated cells. Nucleic Acids Res., 16(3), 1215.

Murdoch, W.J., Colgin, D.C. and Ellis, J.A. 1997. Role of tumor necrosis factor-alpha in the ovulatory mechanism of ewes. J. Anim. Sci., 75(6), 1601-1605.

Perera, B.M.a.O. 2011. Reproductive cycles of buffalo. Anim. Reprod. Sci., 124(3), 194-199.

Powell, J.R. and Dion, K. 2015. Effects of codon usage on gene expression: empirical studies on Drosophila. J. Mol. Evol., 80(3-4), 219-226.

Sabarinathan, R., Tafer, H., Seemann, S.E., Hofacker, I.L., Stadler, P.F. and Gorodkin, J. 2013. RNAsnp: efficient detection of local RNA secondary structure changes induced by SNPs. Hum. Mutat., 34(4), 546-556.

Shirasuna, K., Kawashima, C., Murayama, C., Aoki, Y., Masuda, Y., Kida, K., Matsui, M., Shimizu, T. and Miyamoto, A. 2011. Relationships between the first ovulation postpartum and polymorphism in genes relating to function of immunity, metabolism and reproduction in high-producing dairy cows. J. Reprod. Dev., 57(1), 135-142.

Tantia, M.S., Vijh, R.K., Vij, P.K., Kataria, R.S., Mishra, B.P., Joshi, B.K., Bhasin, V., Gupta, S.C., Pathak, K.M.L., Sikka, P., Yadav, S.P., Pandey, A.K. and Sethi, R.K. 2011. Wholegenome sequence assembly of the water buffalo (Bubalus bubalis). Indian J. Anim. Sci., 81(5),

Wan, Y., Qu, K., Zhang, Q.C., Flynn, R.A., Manor, O., Ouyang, Z., Zhang, J., Spitale, R.C., Snyder, M.P., Segal, E. and Chang, H.Y. 2014. Landscape and variation of RNA secondary structure across the human transcriptome. Nature, 505(7485), 706-709. 